Article

\title{
Does the Introduction of Alien Species Represent a Sanitary Threat for Native Species? The Case of the Eastern Cottontail Sylvilagus floridanus in Italy
}

\author{
Paolo Tizzani ${ }^{*}+\mathbb{D}$, Daniela Andrade ${ }^{\dagger}$, Anna Rita Molinar Min $\mathbb{D}^{D}$, Andrea Peano $\mathbb{D}^{\circ}$ and \\ Pier Giuseppe Meneguz \\ Department of Veterinary Sciences, University of Turin, Largo Paolo Braccini 2, 10095 Grugliasco, Italy; \\ daniela_andrade@msn.com (D.A.); annarita.molinar@unito.it (A.R.M.M.); andrea.peano@unito.it (A.P.); \\ piergiuseppe.meneguz@unito.it (P.G.M.) \\ * Correspondence: paolo.tizzani@unito.it \\ + These authors contributed equally to the work.
}

Received: 26 April 2020; Accepted: 4 August 2020; Published: 6 August 2020

check for updates

\begin{abstract}
Introduction of alien species is a well-known threat to biodiversity. Where newly introduced, alien species may pose a risk for the local ecological community by competing for resources or by introducing pathogens. Sylvilagus floridanus is an American lagomorph introduced into Europe in the second half of 20th century, for hunting. This study evaluated the structure and epidemiological characteristics of the gastrointestinal parasite community in an introduced population of S. floridanus in the Province of Alessandria (Piedmont Region-Italy). Three alien parasites were reported out of 271 animals: Obeliscoides cuniculi in the stomach, Trichostrongylus calcaratus in the small intestine, and Passarulus nonnanulatus in the large intestine. All these nematodes are commonly reported in S. floridanus in its natural range, but they represent alien species in Europe. The report of these alien parasites is an example of the unexpected consequences caused by the introduction of non-native vertebrates. The documented introduction of new pathogens may alter the parasite community of the native lagomorphs, with possible long-term effects on local ecological dynamics.
\end{abstract}

Keywords: Sylvilagus floridanus; alien parasites; invasive species; sanitary risk

\section{Introduction}

More than 16,000 alien species are established outside their native range at a global level [1]. Around one thousand have documented ecological effects, and the taxonomic groups causing the highest impacts are terrestrial invertebrates and terrestrial plants [2]. Alien species might represent a threat to biodiversity, leading to the extinction of indigenous species. They are harmful in different ways: by competing for resources, inter-breeding, or introducing alien pathogens [1]. Few studies on the introduction of alien parasites have been carried out for both terrestrial and aquatic animals. Most of them are reported in fishes, and only a few in mammals. In most cases, the impact of the introduced parasite is significantly higher on the native species than on the co-introduced alien host, raising important concerns about the sanitary threat represented by the biological invasions [3].

The Eastern cottontail Sylvilagus floridanus is a native American lagomorph, whose range extends from southern Manitoba and Quebec to Central and north-western South America. In the United States, the Eastern cottontail ranges from the east to the Great Plains in the west [4]. It is a species with the capacity to adapt to a variety of environmental conditions, as it is able to use diverse and fragmented habitats $[5,6]$. For this reason, after introduction in new areas it can become invasive and quickly expand its range [7], competing with other lagomorphs for space and resources [5]. S. floridanus was 
introduced for hunting in several European countries during the second half of the 20th century: France (1953), Italy (1966), Spain (1980), and Switzerland (1982) [8,9]. Hunting is an activity supported by the movement, translocation, and introduction of millions of animals. In particular, $24.3 \%$ of mammals and $30.2 \%$ of birds introduced into Europe during the last century were released for hunting [10].

The only population of S. floridanus that was permanently established in Europe is the Italian one [11]. Twelve individuals were released in Turin Province (Piedmont Region-Northwestern Italy) [12]. Following additional releases [8], the population quickly spread, and it is now present in North and Central Italy [13]. In Italy, the Eastern cottontail is well adapted to human-disturbed habitats, especially agricultural landscapes mixed with patches of natural vegetation [14]. In these areas, S. floridanus may act as a biological competitor of the native European brown hare Lepus europaeus [15]. Several studies have suggested there is competition for space and food between the cottontail and other lagomorphs [7,16-18], but hares and cottontails can coexist if the shared habitats present a high degree of heterogeneity $[14,19]$. Recent studies have highlighted the possibility of indirect competition by a disruption of predator-prey dynamics [20]. The massive abundance of cottontails causes an increase in predator (fox Vulpes vulpes) presence, with detrimental effects on hare populations. The introduction of S. floridanus in Italy is an example of a biologic invasion following the uncontrolled release of an alien species. Biological invasions are considered among the major threats to biodiversity [21,22]. Invasive species may introduce viruses, bacteria, and parasites to which native species are more susceptible [23-27]. Parasites are also able to adapt to new ecological situations through selection of genotypes particularly suitable for the new environment [28]. Considering competition with native species and the demonstrated role in introducing exotic pathogens, S. floridanus can be definitively considered an invasive species with negative effects at an ecosystem level. The introduction or elimination of a parasite in an ecosystem can strongly affect the interactions between a diverse range of species in the community, and hence affect biodiversity [29].

The gastrointestinal community of Eastern cottontails in its native range is very diverse with at least thirty different gastrointestinal parasites reported: 11 cestodes, one trematode, and 18 nematodes [30-44]. Among them, the most frequently reported are Taenia pisiformis, Obeliscoides cuniculi, Dermatoxys veligera, Trichuris leporis, Trichostrongylus calcaratus, and Hasstilesia tricolor. Species reported at high or low prevalence are reported in Table 1.

Table 1. A selection of the main parasite species described in S. floridanus, with high or low prevalence and maximum prevalence values reported.

\begin{tabular}{ccc}
\hline Parasite Species & Prevalence Category & Maximum Prevalence Reported \\
\hline Trichostrongylus calcaratus & High & $85.0 \%$ \\
Obeliscoides cuniculi & High & $96.0 \%$ \\
Trichostrongylus affinis & High & $71.0 \%$ \\
Longistriata noviberiae & High & $72.0 \%$ \\
Nematodirus leporis & Low & $15.2 \%$ \\
Passalurus nonanulatus & Low & $17.9 \%$ \\
Trichuris sylvilagi & Low & $3.2 \%$ \\
Physaloptera sp. & Low & $1.0 \%$ \\
Gongylonema pulchrum & Low & $1.0 \%$ \\
\hline
\end{tabular}

Since its introduction in Italy in 1966, few studies have been carried out on this species. Among them, some evaluate sanitary threats from the presence of this alien species including macro- [45-51] and microparasites [52,53]. These studies reported exotic parasites (O. cuniculi) in native lagomorphs (Oryctolagus cuniculus and L. europaeus), as well as some preliminary data on the parasite community in S. floridanus. A couple of studies deal with the role of $S$. floridanus in the dynamics of important viral diseases, such as European Brown Hare Syndrome and Rabbit Haemorragic disease $[52,53]$. 
While acknowledging previous work on the health status of $S$. floridanus, the lack of extensive sanitary monitoring and sampling of the Eastern cottontail motivated this study of the structure and epidemiological characteristics of the gastrointestinal parasite community in a high-density population of S. floridanus in Italy.

\section{Materials and Methods}

\subsection{Study Area}

The study was carried out in the Province of Alessandria (Piedmont Region-Italy), which covers an area of 25,383 $\mathrm{km}^{2}$, with $29 \%$ lowlands and $71 \%$ mountains and hills [54]. Three different zones ("Roleto", "Tollara", and "Sezzadio"), where there are high population densities of S. floridanus (30-40 animals $/ \mathrm{km}^{2}$ ), were selected for parasite monitoring (Figure 1) [14]. The first introduction of S.floridanus in the Piedmont took place in 1966, in the municipality of Pinerolo (Piedmont, Northern Italy), where three males and nine females were released along the Pellice river. From there, the species slowly spread to the rest of the region, including the Province of Alessandria. In the 1980s, the Eastern cottontail was very localized in the Alessandria Province. The introduced ranges underwent a marked increase in 1996/1997 and expanded throughout most of the province in the following years [12]. The Eastern cottontail shares these zones with the European hare L. europaeus, whose density varies according to restocking programs and habitat quality, up to a maximum density of 50 hares/ha [55]. In recent years, a decline in the hare population has been observed (Province of Alessandria-unpublished data) while the Eastern cottontail increased its range and density [14,15]. This observation suggests a potential ongoing competition between the two species. The dynamics of the two species in the Alessandria Province is highlighted in Figure 2, which shows the number of L. europeaus and S. floridanus estimated in protected areas from 1998-2011, following the first observation of Eastern cottontails in this zone. The observed trend of the two species, even if they suggest some competition between European hares and Eastern cottontails, should be cautiously interpreted, as the European hare population was already decreasing before the introduction of the Eastern cottontail. A comparison with L. europaeus dynamics in areas without $S$. floridanus would be necessary to derive more robust conclusions (but is outside of the scope of the present work).



Figure 1. Alessandria Province (Italy), the three study areas (Roleto, Tollara, and Sezzadio) are marked in red. 


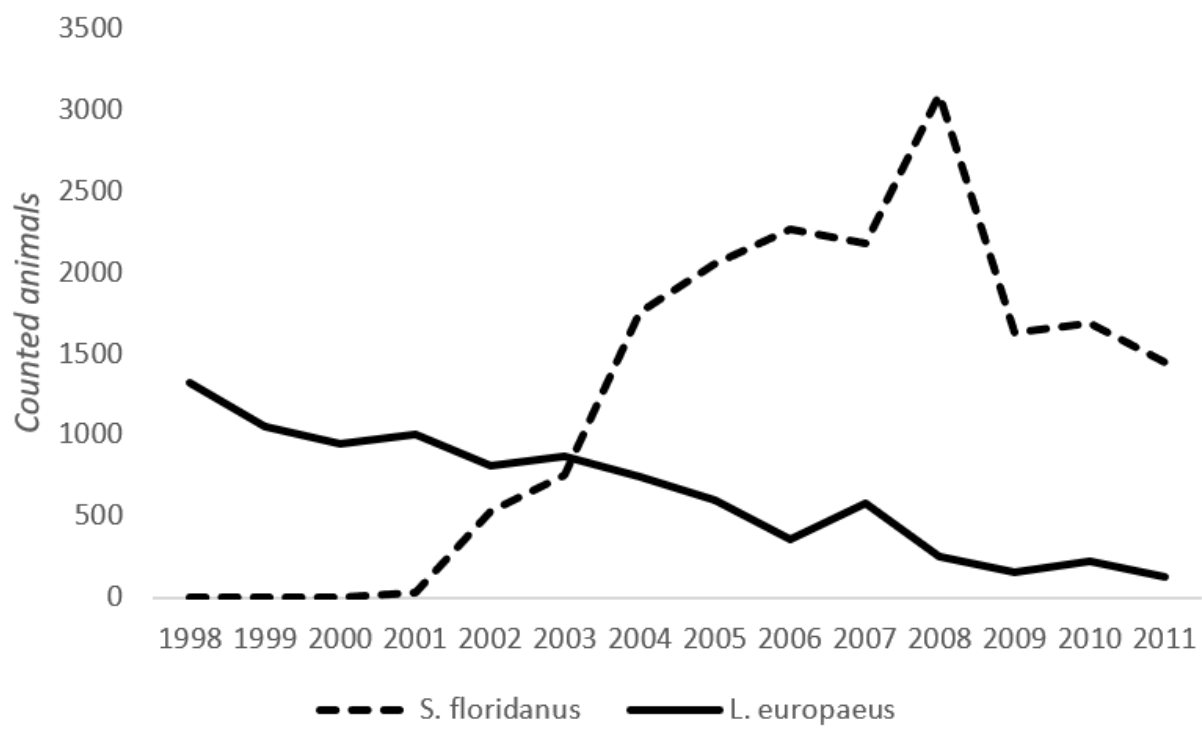

Figure 2. Dynamics of L. europaeus and S. floridanus in a protected area located in Alessandria Province during the period from 1998-2011.

\subsection{Sample Collection}

The sample of S. floridanus included animals shot under a program for the control and eradication of the species (as per article 29 of the Piedmont Regional Law n. 70/96). Beginning in 1999, the Alessandria Province started a program that permitted extensive hunting and capture of Eastern cottontails to control and eventually eradicate the species from the territory. Authorized operators conducted the program and recorded all the killed animals in a field registry. This operation is ongoing. The animals examined for our study were collected from June 2016-May 2017. Sex and weight were registered, and animals were grouped into two age classes: younger and older than six months, according to body weight [56]. Although body weight is not a completely accurate indicator of age, it provides a rough indication of physical maturity [57]. A total of 271 animals were collected: 90 in Tollara (46 males/44 females); 90 in Roleto (45 males/45 females); and 91 in Sezzadio (41 males/50 females). The distribution of the sample by age is shown in Table 2. The average weight of animals in the three study areas was $1042.07 \mathrm{~kg}+/-210.46$ in Tollara, $1071.93 \mathrm{~kg}+/-245.07$ in Roleto, and $1052.33 \mathrm{~kg}+/-$ 241.28 in Sezzadio. The average weight of females was $1119.96 \mathrm{~kg}+/-259.13$ versus $987.84 \mathrm{~kg}+/-$ 177.69 for males.

Table 2. Eastern cottontails divided by age group and study area.

\begin{tabular}{cccc}
\hline Age Class & Tollara & Roleto & Sezzadio \\
\hline Younger than six months & $52(57.78 \%)$ & $49(54.44 \%)$ & $52(57.14 \%)$ \\
Older than six months & $38(42.22 \%)$ & $41(45.56 \%)$ & $39(42.86 \%)$ \\
\hline
\end{tabular}

\subsection{Parasitological Analysis}

Necropsy was carried out for all the animals. The stomach was opened along the greater curvature; small and large intestines were opened longitudinally. The contents were washed into individual jars and settled for $30 \mathrm{~min}$. The sediment was shed into a Petri dish with a black background. The content was diluted in $1 \mathrm{~L}$ of water, and $10 \%$ of the total was examined. If no parasite was found, the rest of the content was inspected. Parasites were stored in Eppendorf tubes with 70\% ethanol [58], observed with

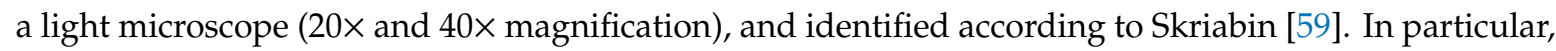
the shape and size of spicula, gubernaculum, and other reproductive structures of the nematodes were used to identify the parasite to the species level. 


\subsection{Epidemiological Analysis}

Nematode prevalence ( $\mathrm{P}-$ percentage of infected animals), intensity (I-mean number of parasites per infected animals), and abundance (A-mean number of parasites per examined host) were computed. Data were analyzed using R 3.5.0 software [60]. Descriptive statistics were used to characterize variations in the main epidemiological indices among the three study areas.

\section{Results}

Three nematode species were identified: O. cuniculi in the stomach, T. calcaratus in the small intestine, and P. nonannulatus in the large intestine. Their prevalence (P), intensity (I), and abundance (A) are reported in Table 3.

Table 3. Prevalence \% (P), mean intensity (I), mean abundance (A), standard deviations (SD), median (Med), minimum (m), and maximum $(\mathrm{M})$ values of the parasite species.

\begin{tabular}{cccccccc}
\hline Parasite & P & I (SD) & A (SD) & Med & m & M & Study Area \\
\hline \multirow{3}{*}{ O. cuniculi } & 93 & $77.55(91.57)$ & $72.38(90.54)$ & 42.5 & 0 & 430 & Roleto \\
\cline { 2 - 7 } & 84 & $52.68(92.39)$ & $44.49(86.96)$ & 20 & 0 & 770 & Tollara \\
\cline { 2 - 7 } & 5 & $23.4(38.04)$ & $1.29(9.65)$ & 0 & 0 & 90 & Sezzadio \\
\hline \multirow{3}{*}{ T. calcaratus } & 90 & $234.23(347.12)$ & $210.81(336.6)$ & 72 & 0 & 1778 & Roleto \\
\cline { 2 - 7 } & 87 & $286.99(463.95)$ & $251.91(444.5)$ & 79.5 & 0 & 2550 & Tollara \\
\hline P. nonannulatus & 68 & $196.5(313.27)$ & $172.73(301.6)$ & 32 & 0 & 1560 & Sezzadio \\
\hline
\end{tabular}

The parasite community structure was quite different in the three study areas. In Sezzadio, O. cuniculi showed lower values for both prevalence ( $\mathrm{P}=5 \%$, compared to the $84 \%$ registered in Tollara and $93 \%$ in Roleto), intensity (average of 23.4 vs. 52.68 and 77.55 recorded in Tollara and Roleto, respectively), and abundance (average of 1.29 vs. 44.49 and 72.38 recorded in Tollara and Roleto, respectively) (Figure 3). T. calcaratus showed similar prevalence values among areas. Also in this case, Sezzadio was the zone with lowest abundance and intensity values. Finally, P. nonannulatus was found only in one sampling area (Roleto), at quite high prevalence, abundance, and intensity.
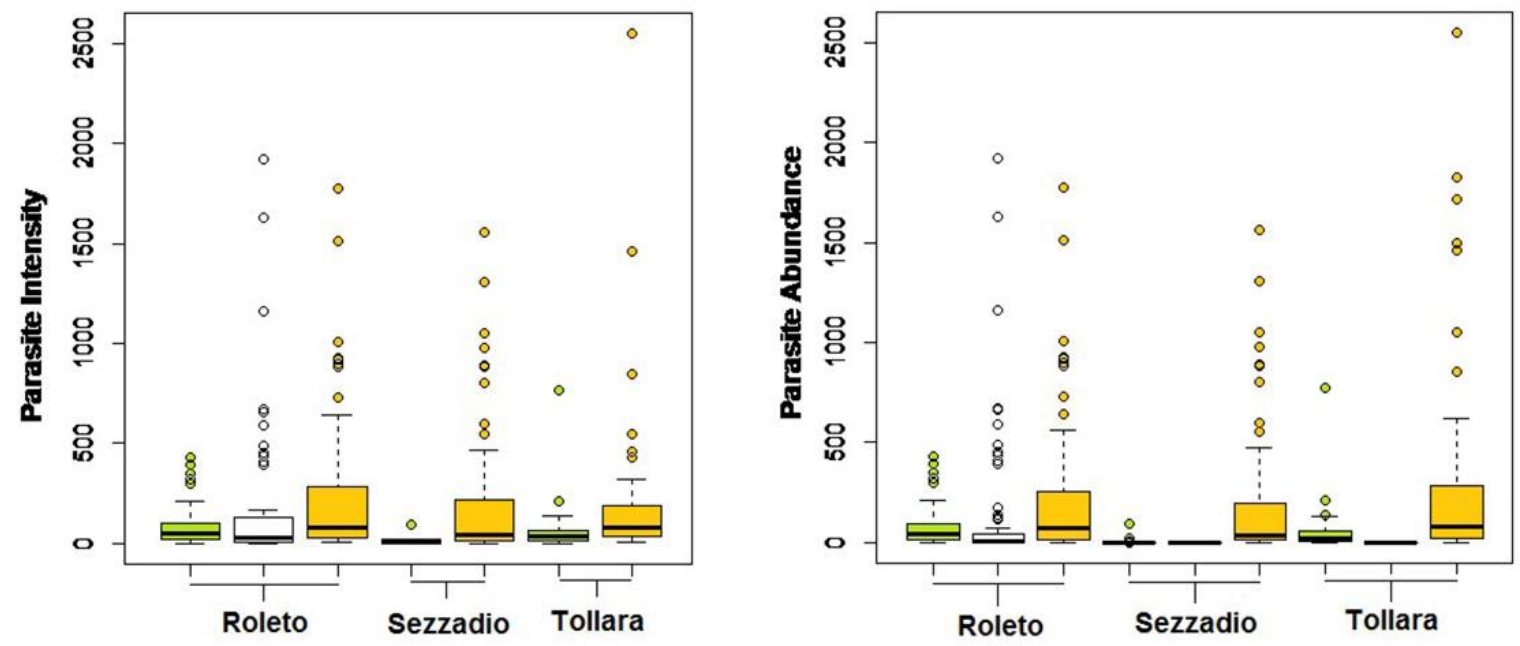

Figure 3. Intensity and abundance of the three parasites by study area (O. cuniculiP. nonannulatus- $\square$; T. calcaratus- $\square$ ). 


\section{Discussion}

This work was carried out to shed light on the parasite community of an invasive species outside its natural range. The sample size in this study was quite large compared to previously published studies on Eastern cottontail parasites [33,37,44], allowing accurate estimation of the main epidemiological indices of the parasite community. The sex ratio ratio and age distribution in our sample are within previously reported ranges [61]. The mean weight of the females was higher than that of the males, in line with previous studies [57,62-64]. These data allowed us to consider the sample collected as representative of a typical Eastern cottontail population.

The main result of the study is the finding of three non-native parasite species. The occurrence of these exotic species was noted in previous works [47-51] but without an extensive sanitary surveillance. Our work describes the main epidemiological indices of an Eastern cottontail parasite community outside its native range, highlighting some key ecological findings.

The parasite richness detected in our study was significantly lower than that reported for S. floridanus in its native range. We identified only three species out of the 30 gastrointestinal helminths reported in literature, corresponding to a $90 \%$ reduction in parasite community richness. Reductions of parasite richness in an introduced species may bring just a "selection" of the original parasite community [65]; moreover, the higher fitness of an introduced species can be explained by the enemy release hypothesis [66]. Specifically, in its native range, a species has co-evolved with several factors (pathogens, parasites, predators) that limit its population. When introduced into a new area, it leaves these limiting factors behind, improving its fitness. On the contrary, we did not find any parasite species typical of the native lagomorphs, suggesting either a strong adaptation of the Eastern cottontail to its parasites or a resistance to local infections.

O. cuniculi was present in all three zones with a prevalence similar to previous reported [33,44]. In particular, the prevalence in Roleto (93\%) and Tollara (84\%) is among the highest reported in the literature $[38,39,44]$. Lower prevalence, as in Sezzadio (5\%), has been reported by Moore and Moore [33] in Alaska (0.58\%), Alabama (8.8\%), and Oklahoma (10.9\%). Also, the intensity values in Roleto (77.55) and Tollara (52.68) were higher than those reported in the literature (maximum of 31 parasites per animal) $[41,42,44]$.

T. calcaratus was found in all the study areas, also in this case with higher prevalence (Roleto $90 \%$, Tollara 87\%, Sezzadio 88\%) than that reported in the native range (between 3.1\% [34] and 85\% [39]). Abundance was similar (172.73-251.91) to what has been described by Boggs et al. (117.7-405.9) [36], while intensities (Roleto 234.23, Tollara 286.99, Sezzadio 196.5) were higher than those reported in Kentucky (12 nematodes per infected animal) [41] and in Illinois (80 nematodes per infected animal) [44].

P. nonannulatus was found only in Roleto, also in this case with a prevalence (62\%) higher than that reported by Moore and Moore (0.6\%) [33] and Erickson (17.9\%) [34]. The absence of this parasite in Tollara and Sezzadio might be due to either a different origin of the introduced S. floridanus population or an earlier extinction of this nematode. Roleto is a lowland zone while Tollara and Sezzadio are hilly areas, thus different environmental conditions might have limited the presence of this parasite. The three species found in this study are among the ones with the highest prevalence described for Eastern cottontail. The parasite species "left behind" are, in fact, those that are less prevalent in native populations [65]. In the Alessandria Province, parasite prevalence was among the highest ever reported in the Eastern cottontail. All the epidemiological indices of the three parasites clearly described a parasite community less diverse but with significantly higher prevalence, intensity, and abundance values than the ones reported in the native range. The loss of some species and the consequent reduction of interspecific competition at the parasite community level may have provided better conditions for these parasites to colonize the host more severely.

The parasite community structure was quite variable among the sampling areas. As previously stated, differences related to sampling areas may suggest that the introduced populations have distinct origins. Other factors include environmental conditions that could influence the development of the parasite's infective larval stages $[67,68]$. 
The lack of natural enemies can favor the ecological success of introduced species [65]. When an invasive species leaves some parasites behind, release from those parasites can cause a demographic explosion leading to higher population densities and average body weight [69]. The reduced parasite richness observed in the introduced Eastern cottontail may contribute to the success of S. floridanus in colonizing new areas. Considering the above, the ecological impact of S. floridanus is of concern, as the release of this lagomorph caused the introduction of four alien species in a new ecosystem: one mammal and three nematodes. The presence of the parasite species was undetected for several decades, and their effects at an ecosystem level are unknown.

The risk of spillover of these parasites to native lagomorphs is quite high. This phenomenon has been reported for the European brown hare in the same area for some nematode species $[47,49]$, and it could potentially cause parasite-mediated competition with unknown consequences for the ecological balance of native animal populations. On the other hand, no public health concern has been highlighted in our study, as none of the introduced nematodes is zoonotic. Further studies on S. floridanus sanitary status in Italy and on the parasite epidemiological characteristics in sympatric wild lagomorph populations are needed to better understand how this scenario may evolve and the possible long-term consequences on biodiversity conservation.

Author Contributions: Conceptualization, P.T. and P.G.M.; methodology, P.T.; validation, P.T.; formal analysis, P.T.; investigation, P.T. and P.G.M.; resources, P.T., D.A., A.R.M.M., A.P. and P.G.M.; data curation, P.T., D.A., and A.R.M.M.; writing-original draft preparation, P.T., and D.A.; writing-review and editing, P.T., D.A., A.R.M.M., A.P. and P.G.M.; visualization, P.T., and D.A.; supervision, P.G.M.; project administration, P.G.M.; funding acquisition, P.G.M. All authors have read and agreed to the published version of the manuscript.

Funding: This research was funded by Alessandria Province.

Acknowledgments: A special acknowledgement to Ennio Negri, Franco Volpara, and to all the hunting guards of Roleto, Tollara, and Sezzadio.

Conflicts of Interest: The authors declare that they have no conflict of interest.

Ethical Approval: All applicable international, national, and/or institutional guidelines for the care and use of animals were followed.

\section{References}

1. Seebens, H.; Blackburn, T.M.; Dyer, E.E.; Genovesi, P.; Hulme, P.E.; Jeschke, J.M.; Pagad, S.; Pyšek, P.; Winter, M.; Arianoutsou, M.; et al. No saturation in the accumulation of alien species worldwide. Nat. Commun. 2017, 8, 1-9. [CrossRef] [PubMed]

2. Vilà, M.; Basnou, C.; Pyšek, P.; Josefsson, M.; Genovesi, P.; Gollasch, S.; Hulme, P.E. How well do we understand the impacts of alien species on ecosystem services? A pan-European, cross-taxa assessment. Front. Ecol. Environ. 2010, 8, 135-144.

3. Lymbery, A.J.; Morine, M.; Kanani, H.G.; Beatty, S.J.; Morgan, D.L. Co-invaders: The effects of alien parasites on native hosts. Int. J. Parasitol. Parasites Wildl. 2014, 3, 171-177. [CrossRef] [PubMed]

4. Chapman, J.A.; Hockman, J.G.; Ojeda, C.M.M. Sylvilagus floridanus. Mamm. Species 1980, 136, 1-8. [CrossRef]

5. Chapman, J.A.; Flux, J.E.C. Rabbits, Fares and Pikas: Status Survey and Conservation Action Plan; International Union for Conservation of Nature and Natural Resources: Gland, Switzerland, 1990; pp. 102-103.

6. Fuller, S.; Tur, A. Conservation Strategy for the New England Cottontail (Sylvilagus transitionalis); University of Nebraska: Lincoln, NE, USA, 2012; p. 148.

7. Vidus-Rosin, A.; Gilio, N.; Meriggi, A. Introduced lagomorphs as a threat to "native" lagomorphs: The case of the Eastern cottontail (Sylvilagus floridanus) in northern Italy. In Lagomorph Biology; Springer: Berlin/Heidelberg, Germany, 2008; pp. 153-164.

8. Spagnesi, M. Silvilago Sylvilagus floridanus (Allen, J.A. 1890). In Mammiferi d'Italia; Spagnesi, M., De Marinis, A.M., Eds.; Quaderni di Conservazione della Natura, Min. Politiche Agricole e Forestali, Ist. Naz. Fauna Selvatica: Roma, Italy, 2002.

9. Delibes-Mateos, M.; Castro, F.; Piorno, V.; Ramírez, E.; Blanco-Aguiar, J.A.; Aparicio, F.; Mínguez, L.E.; Ferreira, C.C.; Rouco, C.; Ríos-Saldaña, C.A.; et al. First assessment of the potential introduction by hunters of eastern cottontail rabbits (Sylvilagus floridanus) in Spain. Wildl. Res. 2018, 45, 571-577. [CrossRef] 
10. Carpio, A.J.; Guerrero-Casado, J.; Barasona, J.A.; Francisco, S.; Tortosa, F.S.; Vicente, J.; Hillström, L.; Delibes-Mateos, M. Hunting as a source of alien species: A European review. Biol. Invasions 2017, 19, 1197-1211. [CrossRef]

11. Mussa, P.P.; Boano, G. Piemonte. Gestione Faunistica e Legislazione; Eda: Torino, Italy, 1990; p. 220.

12. Doria, G. Silvilago o minilepre Sylvilagus floridanus (Allen). In Animali e Piante Dalle Americhe All'Europa; Capocaccia Orsini, L., Doria, G., Doria, G., Eds.; Sagep Editrice: Genova, Italy, 1991; p. 68.

13. Dori, P.; Scalisi, M.; Mori, E. “An American near Rome” and not only! Presence of the eastern cottontail in Central Italy and potential impacts on the endemic and vulnerable Apennine hare. Mammalia 2019, 83, 307-312. [CrossRef]

14. Bertolino, S.; Perrone, A.; Gola, L.; Viterbi, R. Population Density and Habitat Use of the Introduced Eastern Cottontail (Sylvilagus floridanus) Compared to the Native European Hare (Lepus europaeus). Zool. Stud. 2011, 50, 315-326.

15. Silvano, F.; Acquarone, C.; Cucco, M. Distribution of the eastern cottontail (Sylvilagus floridanus) in the province of Alessandria. Hystrix 2000, 11, 75-78.

16. Arthur, C.P.; Chapuis, J.L. L'introduction de Sylvilagus floridanus en France: Historique, dangers et expérimentation en cours. Compte Rendu Séances Société Biogéographie 1983, 59, 333-356.

17. Leach, K.; Montgomery, W.I.; Reid, N. Biogeography, macroecology and species' traits mediate competitive interactions in the order Lagomorpha. Mammal Rev. 2015, 45, 88-102. [CrossRef]

18. Meriggi, A. Sylvilagus floridanus (Allen, J.A. 1890), Silvilago, Minilepre. In Atlante dei Mammiferi della Lombardia; Prigioni, C., Cantini, M., Zilio, A., Eds.; Regione Lombardia: Milano, Italy, 2001; pp. 144-146.

19. Vidus-Rosin, A.; Montagna, A.; Meriggi, A.; Perez, S.S. Density and habitat requirements of sympatric hares and cottontails in northern Italy. Hystrix 2009, 20, 101-110.

20. Cerri, J.; Ferretti, M.; Bertolino, S. Rabbits killing hares: An invasive mammal modifies native predator-prey dynamics. Anim. Conserv. 2017, 20, 511-519. [CrossRef]

21. IUCN. IUCN Guidelines for the Prevention of Biodiversity Loss caused by Alien Invasive Species. In Proceedings of the 51st Meeting of the IUCN Council, Gland, Switzerland, 9 February 2000.

22. Mack, R.N.; Simberloff, D.; Londsdale, W.M.; Evans, H.; Clout, M.; Bazzaz, F.A. Biotic invasions: Causes, epidemiology, global consequences, and control. Ecol. Appl. 2000, 10, 689-710. [CrossRef]

23. Balbo, T.; Lanfranchi, P.; Rossi, L.; Meneguz, P.G. Health management of a red deer population infected by Fascioloides magna. Ann. Fac. Med. Veteterinaria Torino 1987, 32, 3-13.

24. Galil, B.S. A Sea Under Siege-Alien Species in the Mediterranean. Biol. Invasions 2000, 2, 177-186. [CrossRef]

25. Wolff, W.J.; Reise, K. Oyster Imports as a Vector for the Introduction of Alien Species into Northern and Western European Coastal Waters. In Invasive Aquatic Species of Europe. Distribution, Impacts and Management; Springer: Dordrecht, The Netherlands, 2002; pp. 193-205.

26. Taraschewski, H. Hosts and parasites as aliens. J. Helminthol. 2006, 80, 99-128. [CrossRef]

27. Crowl, T.A.; Crist, T.O.; Parmenter, R.R.; Belovsky, G.; Lugo, A.E. The spread of invasive species and infectious disease as drivers of ecosystem change. Front. Ecol. Environ. 2008, 6, 238-246. [CrossRef]

28. Poulin, R. Evolutionary Ecology of Parasites, 2nd ed.; Princeton University Press: Princeton, NJ, USA, 2007; p. 342.

29. Thomas, F.; Guegan, J.F.; Renaud, F.; Guegan, J.F. Parasitism and Ecosystems; Oxford University Press: Oxford, UK, 2005.

30. Ward, J.W. A study of some parasites of rabbits of central Oklahoma. In Proceedings of the Oklahoma Academy of Science; University of Oklahoma: Norman, OK, USA, 1933; pp. 31-32.

31. Morgan, B.B.; Waller, E.F. A Survey of the Parasites of the Iowa Cotton-Tail (Sylvilagus floridanus mearnsi). J. Wildl. Manag. 1940, 4, 21-26. [CrossRef]

32. Smith, C.C. Notes on the Food and Parasites of the Rabbits of a Lowland Area in Oklahoma. J. Wildl. Manag. 1940, 4, 429-431. [CrossRef]

33. Moore, E.R.; Moore, G.C. The Helminth Parasites of Cottontail Rabbits in Alabama, with Notes on the Arthropod Linguatula serrata. J. Mammal. 1947, 28, 279-284. [CrossRef] [PubMed]

34. Erickson, A.B. Helminth Parasites of Rabbits of the Genus Sylvilagus. J. Wildl. Manag. 1947, 11, $255-263$. [CrossRef]

35. Dorney, R.S. Helminth Infections in Wintering Cottontails. J. Wildl. Manag. 1963, 27, 175-179. [CrossRef] 
36. Franklin, J.; Simmons, M.L.; Cosgrove, G.E. A pathogen survey in the Kansas cottontail. J. Wildl. Dis. 1966, 2, 52-53. [CrossRef]

37. Novlesky, M.A.; Dyer, W.G. Helminths of the eastern cottontail rabbits, Sylvilagus floridanus, from North Dakota. Am. Midl. Nat. 1970, 84, 267-269. [CrossRef]

38. Forsythe, S.W. Parasites of Cottontail Rabbits in Lyon Country, Kansas. Doctoral Dissertation, Department of Biology, Kansas State Teachers College, Emporia, KS, USA, 1974.

39. Andrews, C.L.; Davidson, W.R. Endoparasites of selected populations of cottontail rabbits (Sylvilagus floridanus) in the Southeastern United States. J. Wildl. Dis. 1980, 16, 395-401. [CrossRef]

40. Wiggins, J.P. Gastrointestinal parasites of the eastern cottontail (Sylvilagus floridanus) in central Pennsylvania. J. Wildl. Dis. 1980, 16, 541. [CrossRef] [PubMed]

41. Strohlein, D.A.; Christensen, B.M. Metazoan parasites of the eastern cottontail rabbit in western Kentucky. J. Wildl. Dis. 1983, 19, 20-23. [CrossRef]

42. Kietzmann, G.E.; Hugghins, E.J. Helminths of lagomorphs in South Dakota. J. Wildl. Dis. 1986, 22, $276-278$. [CrossRef]

43. Boggs, J.F.; McMurry, S.T.; Leslie, D.M., Jr.; Engle, D.M.; Lochmiller, R.L. Influence of habitat modification on the intestinal helminth community ecology of cottontail rabbit populations. J. Wildl. Dis. 1990, 26, 157-169. [CrossRef]

44. Lepitzki, D.A.W.; Woolf, A.; Bunn, B.M. Parasites of cottontail rabbits in southern Illinois. J. Parasitol. 1992, 78, 1080-1083. [CrossRef]

45. Bertolino, S.; Hofmannova, L.; Girardello, M.; Modry, D. Richness, origin and structure of an Eimeria community in a population of Eastern cottontail (Sylvilagus floridanus) introduced into Italy. Parasitology 2010, 137, 1179-1186. [CrossRef] [PubMed]

46. Meneguz, P.G.; Tizzani, P. Metazoan parasites of the eastern cottontail (Sylvilagus floridanus) in the Province of Alessandria. XXII Congr. Naz. Soc. Ital. Parassitol. 2002, 44, 111.

47. Tizzani, P.; Menzano, A.; Catalano, S.; Rossi, L.; Meneguz, P.G. First report of Obeliscoides cuniculi in European brown hare (Lepus europaeus). Parasitol. Res. 2011, 109, 963-966. [CrossRef]

48. Romeo, C.; Wauters, L.A.; Ferrari, N.; Lanfranchi, P.; Martinoli, A.; Pisanu, B.; Preatoni, D.G.; Saino, N. Macroparasite Fauna of Alien Grey Squirrels (Sciurus carolinensis): Composition, Variability and Implications for Native Species. PLoS ONE 2014, 9, e88002. [CrossRef] [PubMed]

49. Tizzani, P.; Catalano, S.; Rossi, L.; Duignan, P.J.; Meneguz, P.G. Invasive species and their parasites: Eastern cottontail rabbit Sylvilagus floridanus and Trichostrongylus affinis (Graybill, 1924) from Northwestern Italy. Parasitol. Res. 2014, 113, 1301-1303. [CrossRef]

50. Gontero, C.; Fanelli, A.; Zanet, S.; Meneguz, P.G.; Tizzani, P. Exotic Species and Autochthonous Parasites: Trichostrongylus Retortaeformis in Eastern Cottontail. Life 2020, 10, 31. [CrossRef] [PubMed]

51. Fanelli, A.; Ghirardi, M.; Meneguz, P.G.; Tizzani, P. First Report of Obeliscoides cuniculi in the European Rabbit (Oryctolagus cuniculus). Acta Parasitol. 2020. [CrossRef] [PubMed]

52. Lavazza, A.; Cavadini, P.; Barbieri, I.; Tizzani, P.; Pinheiro, A.; Abrantes, J.; Esteves, P.J.; Guido Grilli, G.; Gioia, E.; Mariagrazia Zanoni, M.; et al. Field and experimental data indicate that the eastern cottontail (Sylvilagus floridanus) is susceptible to infection with European brown hare syndrome (EBHS) virus and not with rabbit haemorrhagic disease (RHD) virus. Vet. Res. 2015, 46, 13. [CrossRef] [PubMed]

53. D'Angelo, A.; Cerri, J.; Cavadini, P.; Lavazza, A.; Capucci, L.; Ferretti, M. The Eastern cottontail (Sylvilagus floridanus) in Tuscany (Central Italy): Weak evidence for its role as a host of EBHSV and RHDV. Hystrix Ital. J. Mammal. 2019, 30, 8-11.

54. Gottero, F.; Ebone, A.; Terzuolo, P.; Camerino, P. I Boschi del Piemonte, Conoscenze e Indirizzi Gestionali; Regione Piemonte, Blu Edizioni: Torino, Italy, 2007; p. 240.

55. Malacarne, G. Progetto di Piano Faunistico-Venatorio; Edizione Provincia di Alessandria: Alessandria, Italy, 1999; p. 180.

56. Petrides, G.A. Sex and age determination in the opossum. J. Mammal. 1949, 30, 364-378. [CrossRef]

57. Bothma, J.D.P.; Teer, J.G.; Gates, C.E. Growth and Age Determination of the Cottontail in South Texas. J. Wildl. Manage. 1972, 36, 1209-1221. [CrossRef]

58. MAFF. Manual of Veterinary Parasitological Laboratory Techniques; Her Majesty's Stationary Office: London, UK, 1986; pp. 20-27. 
59. Skrjabin, K.I.; Shikhobalova, N.P.; Schluz, R.S. Essential of Nematodology, Trichostrongylus of Animals and Man; Academy of Sciences of the USSR: Moscow, Russia, 1954; Volume 3, p. 526.

60. R Core Team. A Language and Environment for Statistical Computing. R Foundation for Statistical Computing. 2018. Available online: https://www.r-project.org/. (accessed on 26 April 2020).

61. Bond, B.T.; Bowman, J.L.; Leopold, B.D.; Burger, L.W., Jr.; Godwin, K.D.; Class, C.M. Demographics, morphometrics, and reproductive characteristics of eastern cottontails (Sylvilagus floridanus) in Mississippi. J. Miss. Acad. Sci. 2004, 49, 220-224.

62. Schwartz, C.W. Home range of the cottontail in central Missouri. J. Mammal. 1941, 22, 385-392. [CrossRef]

63. Elder, W.H.; Sowls, L.K. Body weights and sex ratio of cottontail rabbits. J. Wildl. Manag. 1942, 6, $203-207$. [CrossRef]

64. Lord, R.D. The lens as an indicator of age in cottontail rabbits. J. Wildl. Manag. 1959, 23, 358-360. [CrossRef]

65. Torchin, M.E.; Lafferty, M.E.K.; Dobson, A.P.; McKenzie, V.J.; Kuris, A.M. Introduced Species and Their Missing Parasites. Nature 2003, 42, 628-630. [CrossRef]

66. Keane, R.M.; Crawley, M.J. Exotic plant invasions and the enemy release hypothesis. Trends Ecol. Evol. 2002, 17, 164-170. [CrossRef]

67. Stromberg, B.E. Environmental factors influencing transmission of parasites. Vet. Parasitol. 1997, 72, $247-264$. [CrossRef]

68. Maya, C.; Torner-Morales, F.J.; Lucario, E.S.; Hernandez, E.; Jimenez, B. Viability of six species of larval and non-larval helminth eggs for different conditions of temperature, $\mathrm{pH}$ and dryness. Water Res. 2012, 46, 4770-4782. [PubMed]

69. Dobson, A.; May, R.M. Patterns of invasions by pathogens and parasites. In Ecology of Biological Invasions of North America and Hawaii; Mooney, H.A., Drake, J.A., Eds.; Springer: New York, NY, USA, 1986; pp. 57-58.

(C) 2020 by the authors. Licensee MDPI, Basel, Switzerland. This article is an open access article distributed under the terms and conditions of the Creative Commons Attribution (CC BY) license (http://creativecommons.org/licenses/by/4.0/). 